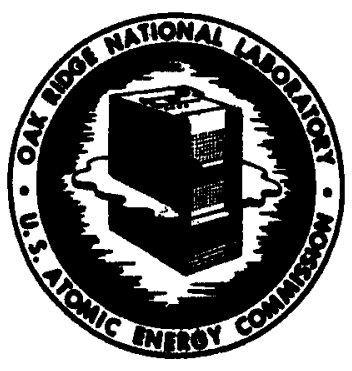

DATE: JuIy 23, 1953

SUBJECT: PRELDMIIAARY BOIITITG EXXPERTIGEMTSS IN THE SUPO MODEL OF THE WATTER BOIIJER

TO:

R. N. Iyon

FROM:
OAK RIDGE NATIOON AL LABORATORY

Operated By

Carbide and Carbon chemicals company

UTC

POST OFFICE BOX $P$

OA I RIDGE, TENNES8EE

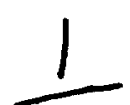

\section{ORNL}

CENTRAL FILES NUMBER

CF-53-7-221

\title{
COPY NO.
}

This document contains 19 pages. This is copy 28 of 33 . Series A.

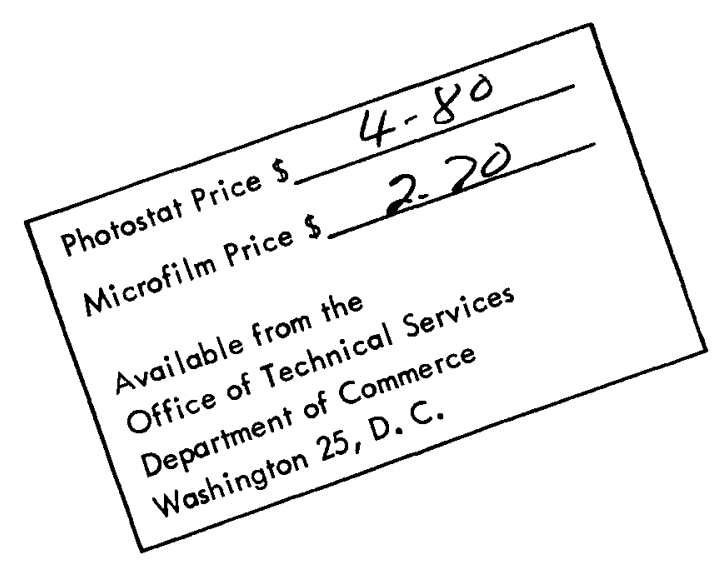




\section{DISCLAIMER}

This report was prepared as an account of work sponsored by an agency of the United States Government. Neither the United States Government nor any agency Thereof, nor any of their employees, makes any warranty, express or implied, or assumes any legal liability or responsibility for the accuracy, completeness, or usefulness of any information, apparatus, product, or process disclosed, or represents that its use would not infringe privately owned rights. Reference herein to any specific commercial product, process, or service by trade name, trademark, manufacturer, or otherwise does not necessarily constitute or imply its endorsement, recommendation, or favoring by the United States Government or any agency thereof. The views and opinions of authors expressed herein do not necessarily state or reflect those of the United States Government or any agency thereof. 


\section{DISCLAIMER}

Portions of this document may be illegible in electronic image products. Images are produced from the best available original document. 
PRELIMTNARY BOILTNG EXPERIMEITIS TN THE SUPO MODEL OF THE WATER BOIIER

SUMMARY
2.

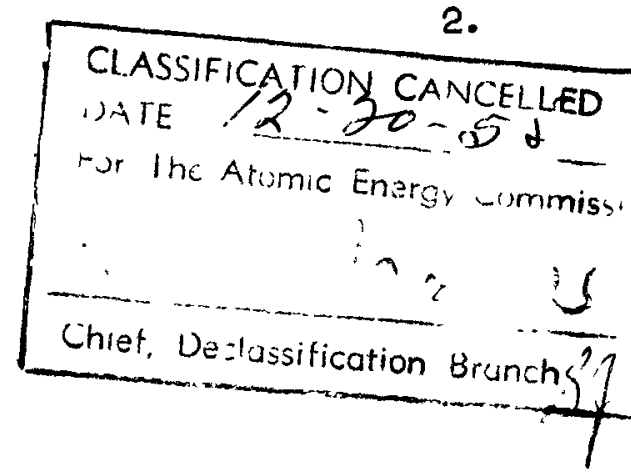

It has been demonstrated that it is possible to operate a homogeneous reactor (Supo model of the Water Boiler) under bolling conditions and that under the particular conditions encountered, a boiling homogeneous reactor is not inherently unistable.

The solution density change on going from non-boiling to bolling conditions has been calculated using the two-group two-region method. The maximum density change found was $0.8 \%$ corresponding to a total nuclear power of $5.4 \mathrm{KW}$. For small reactivity additions the relationship

$$
\frac{\Delta \mathrm{k}}{\mathrm{k}}=0.3 \triangleq \mathrm{d}
$$

is good to $\pm 10 \%$. Average bubble rise rates of $10 \mathrm{ft} / \mathrm{sec}$ were calculated assuming that $1 \mathrm{KW}$ of heat was dissipated in unfform volume bolling. This suggests that the onset of vapor evolution in the solution increased the rate of circulation and thereby the rate of surface evaporation. Disengagement velocities from the free surface of the water boiler were found to be $30-50$ Ibs. of vapor/ $\left(h r_{0}\right)\left(s q \cdot f_{0}\right)$. 


\section{INTRODUCTION}

On November 13 and 14, 1951, R. J. Goldstein, P. R. Kasten, R. N. Lyon and P. C. Zmola of ORRL visited L.D.P. King of Ios Alamos Scientific Iaboratory, and with his cooperation and aid, bolled the supo model of the Water Boiler ${ }^{(1)}$. This was accomplished by stopping the water flow through the internal cooling tubes, the heat generated being removed with a reflux condenser. The purpose of the experiment was to determine whether a bolling reactor was capable of stable operation. The smooth operation of the reactor during the bolling runs demonstrated that, for the particular conditions encountered, a boiling homogeneous reactor is not inherently unstable. The purpose of this memorandum is to describe briefly the qualitative results and to analyze the data obtained during the experiments.

\section{EXPERTMIINAL RESULTS}

Tests were made under three slightly different operating conditions. During the first series of tests there was 880 grams total of $\mathrm{U}^{235}$ in the sphere in $12.9-13.0$ liters of solution. In the second series of tests there was the same amount of uranium but $246 \mathrm{cc}$ less water in the system. The final series of tests were made after 5 grams of $U^{235}$ had been added to the sphere solution. The nominal solution level was $5 \mathrm{~cm}$ below the top of the sphere. For the first two series of tests the following procedure was used. The water flow through the

(1) I.D.P. King, "The Ios Alamos Homogeneous Reactor, Supo Model" Report IA-1301 or AECD-3287, February 7, 1952. 
Internal cooling coil was stopped and the power level was increased until the solution temperature was within $2^{\circ} \mathrm{C}$ of the bolling point. The just non-boiling condition was maintained for 10-15 minutes after the steady state non-bolling readings were obtained. The control rod was withdrawn in a stepwise fashion with 10-20 minute intervals between changes in rod position. In the final test the same procedure was followed except that there was no non-boiling run.

The onset of boiling was assumed to correspond to the approximately IIve fold increase in fluctuations of the power meters. A portion of the chart from The Ieeds-Northup recorder is shown in Figure 1. The chart speed was too slow to allow power fluctuations to be followed, nevertheless it does give a qualitative indication of the change in fluctuations in going from non-boiling to bolling conditions. At the start of the first afternoon's test, the average power fluctuations during bolling were $\pm 20 \%$ at a nuclear power level of $5.19 \mathrm{~kW}$. After $21 / 2$ hours of operation at $5 \mathrm{KW}$ or greater the average power fluctuations had decreased to $\pm 10 \%$. One possible explanation is that in the early tests the cooling colls and steel sphere had not heated up and there was volume bolling of the solution. Whereas in the later tests the cooling colls and steel sphere were in temperature equilibrium and could have been heated enough by gammas and neutrons to allow surface boiling. With the large surfaces available, this would allow more uniform vapor evoluton and thus less fluctuations.

It should be pointed out that in the first series of tests the average power passed through a maximum as the control rod was withdrawn. This was not observed in other tests. 


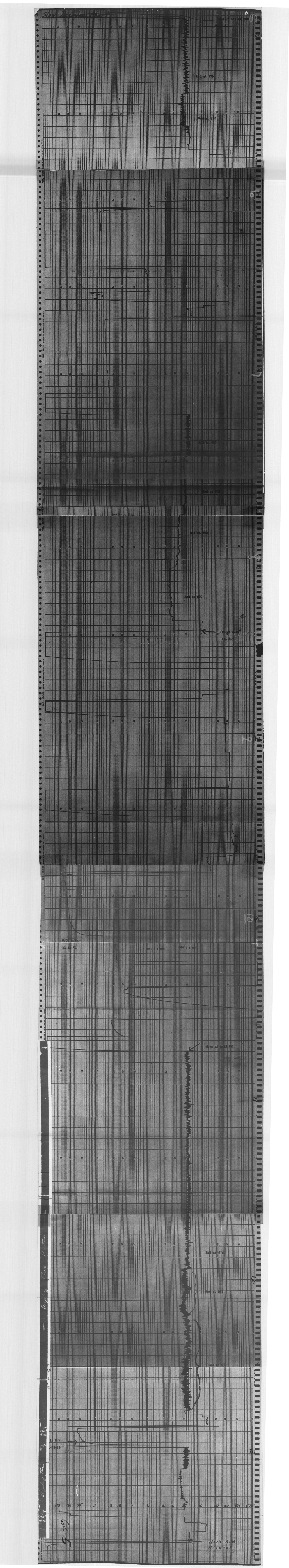




$$
14
$$

6.

The data obtained during these experiments are given in Table 1.

For a bare, spherical homogeneous reactor, the effect of a small change of reactivity on the density can be expressed by

$$
\frac{\Delta k}{k}=2\left(\frac{k-1}{k} \mid \frac{\Delta d}{d}\right.
$$

However since the Supo model of the Water Boiler had an essentially infinite graphite reflector, this equation would not be expected to apply. Therefore two group theory for a spherical homogeneous core and infinite reflector(2) was used to determite the effect of small reactivity changes on the density of the core. Since the model geometry selected did not account for absorption in the core tank, control rods, thimbles, and cooling coils, leakage out the glory hole and condenser passage ways as well as the unsymetrical shape the thermal constants were adjusted using a fictitious $\Sigma_{\text {as }}$ for the stainless steel. The non-bolling test just below the bolling point was used to evaluate the fictitious $\sum \mathbf{a s} \cdot$

The problem was essentually that of solving the following transcendental equation (3):

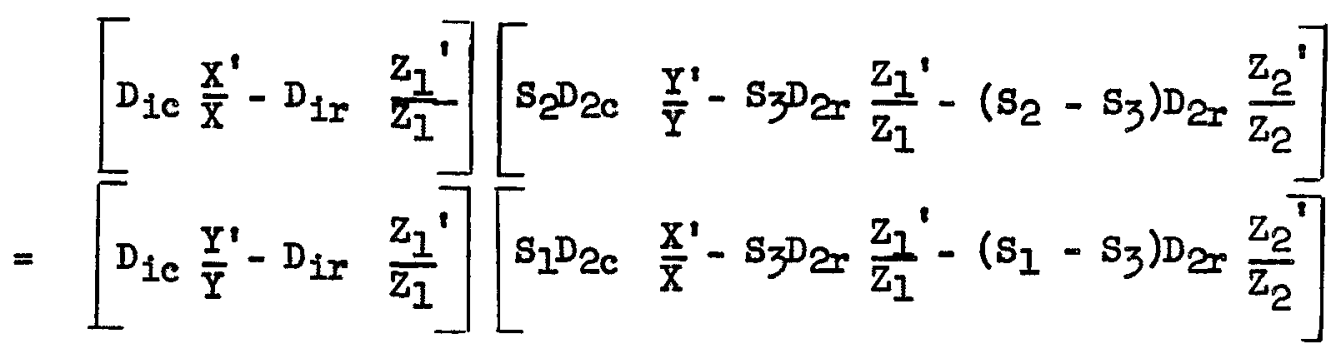

(2) S. Glasstone, M. C. Edlund, "The Elements of Nuclear Reactor Theory," D. Van Nostrand (1952)

(3) Nomenclature is tabulated at the end of the report. 
TABIE I

EXPFRTMENTAL DATA

\begin{tabular}{|c|c|c|c|c|c|c|c|c|c|}
\hline \multirow[b]{2}{*}{ Date } & & \multirow[b]{2}{*}{$\begin{array}{c}\text { Barometer, } \\
\text { mm. } \mathrm{H}_{8} .\end{array}$} & \multirow{2}{*}{$\begin{array}{c}\text { Duration } \\
\text { of Test, } \\
\text { min. }\end{array}$} & \multirow[b]{2}{*}{$\begin{array}{l}\text { NE Rod } \\
\text { Position }\end{array}$} & \multirow[b]{2}{*}{$\begin{array}{l}\text { Sphere } \\
\text { Term., }{ }^{\circ} \mathrm{C}\end{array}$} & \multirow[b]{2}{*}{$\begin{array}{l}\text { Sphere } \\
\text { Condition }\end{array}$} & \multicolumn{2}{|c|}{$\begin{array}{c}\text { Pressure Drop, } \\
\mathrm{Cm} \mathrm{H}_{2} \mathrm{O}\end{array}$} & \multirow{2}{*}{$\begin{array}{l}\text { Circulating } \\
\text { Air Flor, } \\
\frac{\text { liters }}{\text { min }}\end{array}$} \\
\hline & & & & & & & Condenser & $\begin{array}{l}\text { Catalyst } \\
\text { Bed }\end{array}$ & \\
\hline $\begin{array}{l}\text { Nov. } 13 \\
\text { Nov. } 13 \\
\text { Nov. } 1 \\
\text { Nov. } 1 \\
\text { Nov. } 1^{3} \\
\text { Nov. } 1\end{array}$ & $\begin{array}{l}\text { - } \mathbf{A M}^{(1)} \\
\text { - } \mathbf{P M} \\
\text { - } \mathbf{P M} \\
\text { - } \mathbf{P M} \\
\text { - } \mathbf{P M} \\
\text { - } \mathbf{P M}\end{array}$ & $\begin{array}{l}- \\
- \\
- \\
-\end{array}$ & $\begin{array}{l}- \\
15 \\
15 \\
15 \\
20 \\
15\end{array}$ & $\begin{array}{l}610 \\
650 \\
630 \\
676 \\
712 \\
759\end{array}$ & $\begin{array}{l}92.0 \\
93.6 \\
93.0 \\
93.0 \\
93.0 \\
92.9\end{array}$ & $\begin{array}{l}\text { Non Boiling } \\
\text { Boiling } \\
\text { Boiling } \\
\text { Boiling } \\
\text { Boiling } \\
\text { Boiling }\end{array}$ & $\begin{array}{l}5.4 \\
6.3 \\
5.8 \\
6.8 \\
7.2 \\
7.4\end{array}$ & $\begin{array}{l}1.5 \\
1.0 \\
1.2 \\
0.6 \\
0.4 \\
0.2\end{array}$ & $\begin{array}{l}7 \overline{8} \\
85 \\
61 \\
46.5 \\
30\end{array}$ \\
\hline $\begin{array}{l}\text { Nov. } 14 \\
\text { Nov. } 14 \\
\text { Nov. } 14 \\
\text { Nov. } 14\end{array}$ & $\begin{array}{l}-A M^{(2)} \\
-A M \\
-A M \\
-A M\end{array}$ & $\begin{array}{l}589.5 \\
589.5 \\
589.5 \\
589.5\end{array}$ & $\begin{array}{l}15 \\
10 \\
20 \\
15\end{array}$ & $\begin{array}{l}610 \\
700(3) \\
802 \\
948\end{array}$ & $\begin{array}{l}91.8 \\
92.4 \\
92.7 \\
92.8\end{array}$ & $\begin{array}{l}\text { Non Bolling } \\
\text { Non Boiling } \\
\text { Boiling } \\
\text { Boiling }\end{array}$ & $\begin{array}{l}5.0 \\
5.4 \\
6.1 \\
7.0\end{array}$ & $\begin{array}{l}1.8 \\
1.6 \\
1.2 \\
0.5\end{array}$ & $\begin{array}{l}99 \\
96 \\
81 \\
57\end{array}$ \\
\hline $\begin{array}{l}\text { Nov. } 14 \\
\text { Nov. } 14\end{array}$ & $\begin{array}{l}-P M^{(4)} \\
-P M\end{array}$ & $\begin{array}{l}587 \cdot 9 \\
587 \cdot 9\end{array}$ & $\begin{array}{l}15 \\
20\end{array}$ & $\begin{array}{l}728 \\
975\end{array}$ & $\begin{array}{l}92.3 \\
92.3\end{array}$ & $\begin{array}{l}\text { Bolling } \\
\text { Bolling }\end{array}$ & $\begin{array}{l}5 \cdot 7 \\
7 \cdot 2\end{array}$ & $\begin{array}{l}1.4 \\
0.3\end{array}$ & $\begin{array}{l}82 \\
40\end{array}$ \\
\hline
\end{tabular}

(1) 880 Gm 25 total, 12.9-13.0 1iters in system

$y$ (2) 3 dumps since Nov. 13 muns. Total of 246 ce less rater in system.

(3) This corresponds to 610 on the Nov. 13 tests, or a $108 s$ in reactivity equivalent to 5.48 grams of 25 .

(4) Added 5 grams 25 
TABIE 1 (Continued)

EXPERTMENTAL DATA

\begin{tabular}{|c|c|c|c|c|c|c|c|c|c|}
\hline \multirow[b]{2}{*}{ Date } & \multirow[b]{2}{*}{$\begin{array}{l}\text { Neutron } \\
\text { Rate } \\
\text { Meter }\end{array}$} & \multicolumn{3}{|c|}{ Condenser Power } & \multicolumn{5}{|c|}{ Power } \\
\hline & & $\begin{array}{c}\text { Temp., } \\
\begin{array}{c}\text { Condenser } \\
\text { Inlet }\end{array}\end{array}$ & $\begin{array}{c}\text { Condenser } \\
\text { Outlet }\end{array}$ & $\begin{array}{l}\text { Water FIoW } \\
\text { Rate, } \\
\text { Gallons } \\
\text { minute }\end{array}$ & $\begin{array}{c}\text { Power, } \\
\mathrm{KM}\end{array}$ & $\begin{array}{l}\text { KW } \\
\text { Meter } \neq\end{array}$ & $\begin{array}{l}\text { Auto. } \\
\text { cont. } \\
\text { Power } \\
\text { KW* }\end{array}$ & $\frac{\frac{\text { Intermal }}{\text { Counts }}}{\text { min.** }}$ & $\begin{array}{c}\text { Counter } \\
\text { Power } \\
\mathrm{KW} \\
\end{array}$ \\
\hline $\begin{array}{l}\text { Nov. } 13 \text { - } \text { AM }^{(1)} \\
\text { Nov. } 13-\text { PM } \\
\text { Nov. } 13 \text { - PM } \\
\text { Hov. } 13 \text { - PM } \\
\text { Nov. } 13=\text { PM } \\
\text { Hov. } 13=\text { PM }\end{array}$ & $\begin{array}{l}- \\
- \\
- \\
- \\
-\end{array}$ & $\begin{array}{l}7.0 \\
6.5 \\
6.5 \\
6.5 \\
6.5 \\
6.5\end{array}$ & $\begin{array}{l}19.5 \\
24.75 \\
23.77 \\
26.10 \\
26.70 \\
26.40\end{array}$ & $\begin{array}{l}0.80 \\
0.83 \\
0.83 \\
0.83 \\
0.83 \\
0.83\end{array}$ & $\begin{array}{l}2.64 \\
3.92 \\
3.79 \\
4.27 \\
4.43 \\
4.36\end{array}$ & $\begin{array}{l}4.8 \pm 0.3 \\
4.55 \pm 0.5 \\
5.3 \pm 0.5 \\
5.2 \pm 0.2 \\
5.0 \pm 0.2\end{array}$ & $\begin{array}{c}3.60 \\
4.6 \pm 0.4 \\
4.3 \pm 0.4 \\
5.0 \pm 0.5 \\
4.9 \pm 0.1 \\
4.8 \pm 0.3\end{array}$ & $\begin{array}{l}18.7 \\
24.6 \\
22.87 \\
26.36 \\
26.12 \\
25.48\end{array}$ & $\begin{array}{l}3.95 \\
5.19 \\
4.83 \\
5.56 \\
5.51 \\
5.38\end{array}$ \\
\hline $\begin{array}{l}\text { Nov. } 14-\mathrm{AM}^{(2)} \\
\text { Nov. } 14-\mathrm{AM} \\
\text { Iov. } 14-\mathrm{AM} \\
\text { Nov. } 14-\mathrm{AM}\end{array}$ & $\begin{array}{c}- \\
- \\
\pm 4 \\
\pm 3\end{array}$ & $\begin{array}{l}6.0 \\
6.4 \\
6.4 \\
6.3\end{array}$ & $\begin{array}{l}15.6 \\
20.4 \\
24.3 \\
27 \cdot 7\end{array}$ & $\begin{array}{l}0.81 \\
0.82 \\
0.83 \\
0.82\end{array}$ & $\begin{array}{l}2.08 \\
3.03 \\
3.95 \\
4.63\end{array}$ & $\begin{array}{l}2.6 \pm 0.0 \\
3.7 \pm 0.2 \\
4.7 \pm 0.1 \\
5.5 \pm 0.4\end{array}$ & $\begin{array}{l}2.5 \pm 0.0 \\
3.6 \pm 0.1 \\
4.5 \pm 0.2 \\
5.5 \pm 0.5\end{array}$ & $\begin{array}{l}13.28 \\
18.85 \\
23.70 \\
27.85\end{array}$ & $\begin{array}{l}2.80 \\
3.98 \\
5.01 \\
5.88\end{array}$ \\
\hline $\begin{array}{l}\text { Nov. } 14=\mathrm{PM}^{(4)} \\
\text { Nov. } 14-\mathrm{PM}\end{array}$ & $\begin{array}{l} \pm 4 \\
\pm 6\end{array}$ & $\begin{array}{l}5.2 \\
5.6\end{array}$ & $\begin{array}{l}23.2 \\
26.9\end{array}$ & $\begin{array}{l}0.84 \\
0.82\end{array}$ & $\begin{array}{l}3.99 \\
4.63\end{array}$ & $\begin{array}{l}\ddot{4} .9 \pm 0.2 \\
5.6 \pm 0.4\end{array}$ & $\begin{array}{l}4.5 \pm 0.3 \\
5.4 \pm 0.4\end{array}$ & $\begin{array}{l}23.7 \\
28.12\end{array}$ & $\begin{array}{l}5.01 \\
5.93\end{array}$ \\
\hline
\end{tabular}

\# Values given are average values with the \pm limits indicating the maximm fluctuation in the werer reading.

* Power in $\mathrm{KW}=($ counts $/ \mathrm{min}) / 4.74$

* Meter off 6\%; True Power = Power Reading 1.06 
The fast and slow constants which were assumed initially are given in Table 2.

The specific procedure followed was to determine a reproduction constant for the system. Using Equation 3 the fictitious $\sum_{8 s}$ for the stainless steel

$$
\mathrm{k}=\epsilon \mathrm{pf} \eta=\frac{\eta \gamma \sigma_{\mathrm{a} 25}}{\gamma \sigma_{\mathrm{a} 25}+(1-\gamma) \sigma_{\mathrm{a} 28}+2 \sigma_{\mathrm{aN}}+\beta_{\mathrm{H}_{2} \mathrm{O}} \times \sigma_{\mathrm{a}_{\mathrm{H}^{O}}}+\frac{\sum_{\mathrm{as}}}{\mathrm{Nu}}}
$$

was determined then a new value for $L^{2}$ was calculated and Equation $I$ solved again for the reproductive constant. This process was repeated until successive values of $\mathrm{k}$ agreed to within $1 \%$.

In order to determine the density-reactivity relationship, it was assumed that all additions of reactivity caused boiling and therefore solution density changes. Hew solution constants were evaluated from the following relationship.

$$
\begin{aligned}
& I^{2}=I_{0}^{2} \quad{\frac{d_{0}}{d}}^{2} \\
& \zeta=\zeta_{0} \quad{\frac{d_{0}}{d}}^{2} \\
& D=D_{0} \quad \frac{d_{0}}{d}
\end{aligned}
$$

The new reproduction constant corresponding to the reactlvity change on bolling was computed from Equation 3, and the density ratio solved for by iteration.

The value of the reproduction constant for the first non-boiling test changed by less then $1 \%$ on the third approximation, therefore the solution density was calculated for that $k$ and for various reactivity changes. For comparison purposes the density change was also calculated for one point for the first approximation of the reproduction constant. 


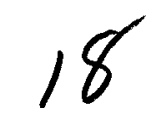

TABIE 2

MUNERICAL CONSTANIS USED FOR CAICULATIONS

\begin{tabular}{|c|c|c|c|c|}
\hline$\tau_{c}$ & $=35.93$ & Uranium & $88.7 \%$ & $u^{235}$ \\
\hline$I_{2 c}^{2}$ & $=1.701$ & Sphere Radius & 15.24 & cm \\
\hline$D_{l c}$ & $=1.185$ & $\sigma_{a}\left(u^{235)}\right.$ & 645 & barns \\
\hline$D_{2 c}$ & $=0.1843$ & $\sigma_{\mathrm{a}}\left(\mathrm{u}^{238}\right)$ & 2.8 & berns \\
\hline$\tau_{x}$ & $=350$ & $\sigma_{a}(N)$ & 1.8 & barns \\
\hline$I^{2} 2 r$ & $=2700$ & $\sigma_{a}\left(H_{2} 0\right)$ & 0.66 & barns \\
\hline$D_{1 r}$ & $=0.9766$ & $p \in \approx I$ & & \\
\hline$D_{2 x}=$ & $=0.903$ & & & \\
\hline
\end{tabular}


The results of the density change calc

The results of the density change calculations for the first series of tests are given in Table 3. The results are plotted in Figure 2 as density ratio against equivalent grams $U^{235}$ added as control rod was withdraw. There is a very nearly Iinear relationship between reactivity addition and density change, the curve being fitted to within $\pm 10 \%$ by the expression

$$
\frac{\Delta k}{k}=0.30 \triangle a
$$

using the values from the third approximation given in Table 3. Equation (1) gives a numerical constant of 0.57 for the bare sphere case compared to the empirical value of 0.30 obtained above for a reflected system. The value given In Equation 7 seems quite reasonable since in a reflected system the density change mast occur in a much smaller volume than in that for an equivalent sphere.

The average solution density decreased by only a maximum of $0.8 \%$ for the maximum reactivity adition. However the average power fluctuations during the boiling runs were $\pm 15-20 \%$ according to the Leeds and Northrup recorder and \pm 5-10\% according to the power meters. If the power fluctuations were due to density fluctuations alone then the vapor generated in volume boiling mast have escaped from the system in surges. For example, if only I KW of power was generated by volume bolling, then for the calculated maximm average density change $(0.8 \%)$, the average escape velocity was about $10 \mathrm{ft} . / \mathrm{sec}$. With this low residence time, the possibility exists that the onset of vapor evolution in the solution caused sufficient circulation to decrease the effective film thickness at the free surface, thereby allowing increased surface evaporation. 


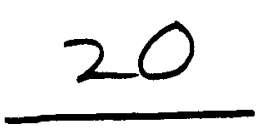

TABLE 3

RESULTS OF DENSITY CALCULATIONS

\begin{tabular}{|c|c|c|c|c|c|c|c|c|c|}
\hline Date & $\begin{array}{l}\text { Sphere } \\
\text { Condition }\end{array}$ & $\begin{array}{l}\text { NE Rod } \\
\text { Position }\end{array}$ & $\begin{array}{l}\text { Control Rod } \\
\text { Equivalent, } \\
\text { Grams } 25\end{array}$ & $\begin{array}{l}\text { Nuclear } \\
\text { Power, } \\
\text { KW }\end{array}$ & $\begin{array}{c}\text { Condenser } \\
\text { Power, } \\
\text { KW }\end{array}$ & $\begin{array}{l}\text { Calculated } \\
\text { Reproduction } \\
\text { Constant }\end{array}$ & $\begin{array}{l}\text { Calculated } \\
\delta \mathrm{k}, \%\end{array}$ & $\begin{array}{c}\text { Exptl. } \\
\delta \mathrm{k}, \phi\end{array}$ & $\begin{array}{l}\text { Calculated } \\
\text { Solution } \\
\text { Density } \\
\text { Ratio } \\
\text { do/a }\end{array}$ \\
\hline $\begin{array}{l}\text { Ist Approx. } \\
\text { Nov. } 13-\text { AM } \\
\text { Nov. } 13 \text { - PM } \\
\text { Nov. } 13-\text { PM }\end{array}$ & $\begin{array}{l}\text { Non Boiling } \\
\text { Bolling } \\
\text { Boiling }\end{array}$ & $\begin{array}{l}610 \\
676 \\
759\end{array}$ & $\begin{array}{r}77.85 \\
7.47 \\
4.43\end{array}$ & $\begin{array}{l}3.95 \\
5.56 \\
5.38\end{array}$ & $\begin{array}{l}2.64 \\
4.27 \\
4.36\end{array}$ & $\begin{array}{l}1.4824 \\
1.4844 \\
1.4858\end{array}$ & $\begin{array}{l}- \\
0.20 \\
0.34\end{array}$ & $\begin{array}{l}- \\
0.15 \\
0.25\end{array}$ & $\begin{array}{l}1.00 \\
-5 \\
1.00589\end{array}$ \\
\hline $\begin{array}{l}\text { 2nd Approx. } \\
\text { Nov. } 13 \text { - AM } \\
\text { 3rd Approx. } \\
\text { Nov. } 13-\text { AM } \\
\text { Nov. } 13-\text { PM } \\
\text { Nov. } 13-\text { PM } \\
\text { Nov. } 13-\text { PM } \\
\text { Nov. } 13-\text { PM } \\
\text { Nov. } 13-\text { PM }\end{array}$ & $\begin{array}{l}\text { Non Boiling } \\
\text { Bolling } \\
\text { Bolling } \\
\text { Bolling } \\
\text { Bolling } \\
\text { Boiling }\end{array}$ & $\begin{array}{l}610 \\
630 \\
650 \\
676 \\
712 \\
759\end{array}$ & $\begin{array}{r}11.85 \\
10.30 \\
8.94 \\
7.47 \\
5.93 \\
4.43\end{array}$ & $\begin{array}{l}3.95 \\
4.83 \\
5.19 \\
5.56 \\
5.51 \\
5.38\end{array}$ & $\begin{array}{l}2.64 \\
3.79 \\
3.92 \\
4.27 \\
4.43 \\
4.36\end{array}$ & $\begin{array}{l}1.4021 \\
1.4028 \\
1.4035 \\
1.4042 \\
1.4050 \\
1.4057\end{array}$ & $\begin{array}{l}- \\
0.07 \\
0.14 \\
0.21 \\
0.29 \\
0.36\end{array}$ & $\begin{array}{l}- \\
0.052 \\
0.097 \\
0.15 \\
0.197 \\
0.25\end{array}$ & $\begin{array}{l}0.9998 \\
1.0016 * \\
1.0033^{*} \\
1.0048 \\
1.0065^{*} \\
1.0079\end{array}$ \\
\hline
\end{tabular}

v

*Tnt,erpolated 
21

Drawing of 20833

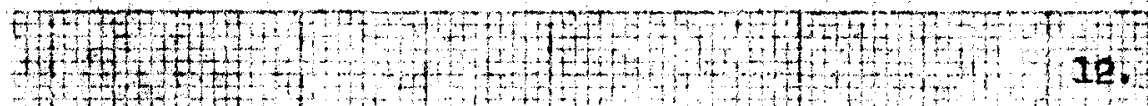

c

1

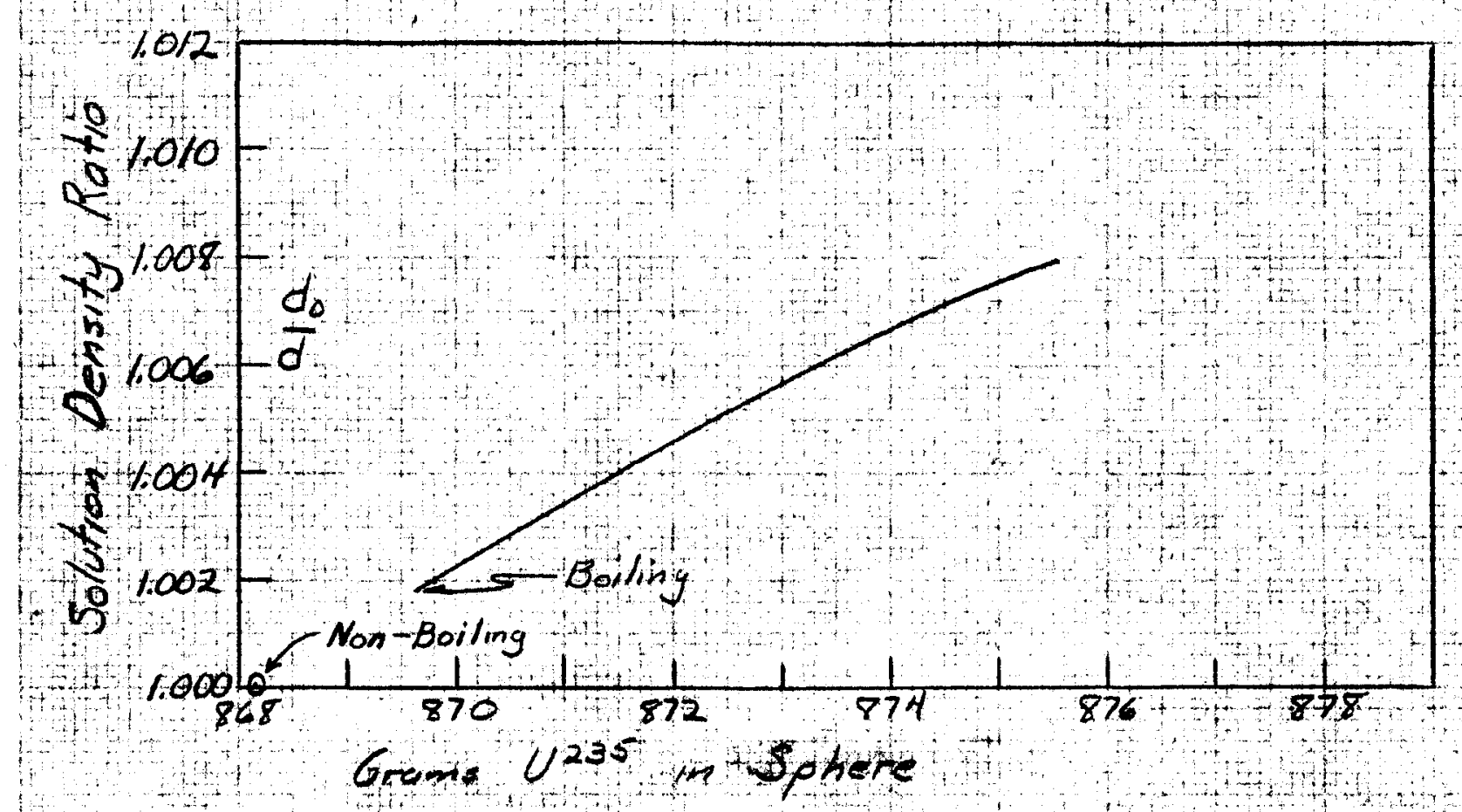

Figure Z, Effect of Reactivity Addition on The Density of the Fuel Solution as the SUPO Model of the Water Boiler was Boiled. 


\section{2}

A brief examination of the literature showed that there seemed to be a limiting disengagement velocity for the vapors from the surface of a boiling Iiquid above which ser1ous entraiment was observed $(4)(5)$. The values quoted ranged between 10 and $50 \mathrm{lbs} /(\mathrm{hr})(\mathrm{sq}$. ft.). Since the solution level in the water boller was not known accurately, it was not possible to calculate the disengagement velocities accurately. In order to estimate values, two cases were assumed. In the first case the just non-boiling solution level was assumed to be at the usual operating level of $5 \mathrm{~cm}$ below the top of the sphere, it was also assumed that there was no holdup in the condenser. Thus the only change in solution level was due to volume bolling of the core solutions as given in Table 3. In the second case, it was assumed that the solution was $5 \mathrm{~cm}$ below the top of the sphere at $20^{\circ} \mathrm{C}$ and expanded as it was heated up to just below the bolling point. Again it was assumed that there was no liquid holdup in the condenser. In both cases the heat removed in the condenser was used to calculate the pounds of steam evaporated per hour. The results of the two calculations are given in Table 4. These data are plotted in Figure 3 as disengagement velocity against equivalent grams $U^{235}$ in the sphere. For comparison purposes the condenser power and nuclear porer curves are also included on this graph.

(4) D. E. Plerce, Ind. Eng. Chem.45, 81A, February, (1953)

(5) Chemical Engineers Handbook, John H. Perry, Editor-in-Chief, McGraw-Hill Book Company, Inc., New York, New York, 3rd Edition (1950) p514 


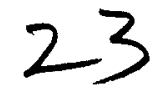

TABIS 4

STEAY DISIEICAGERIAT VEIOCITY FROM FRES SURFACE OF WATHR BOIIER

\begin{tabular}{|c|c|c|c|c|c|}
\hline \multirow{2}{*}{$\begin{array}{l}\text { Sphere } \\
\text { Condition }\end{array}$} & \multirow{2}{*}{$\begin{array}{l}\text { IIE Rod } \\
\text { Position }\end{array}$} & \multirow{2}{*}{$\begin{array}{l}\text { Internal } \\
\text { Counter } \\
\text { Porrer, } \\
\text { KM } \\
\end{array}$} & \multirow{2}{*}{$\begin{array}{c}\text { Condenser } \\
\text { Power, } \\
\mathrm{kw} \\
\end{array}$} & \multicolumn{2}{|c|}{$\begin{array}{c}\text { Disengagement velocity } \\
\text { Ib./(br)(sq. ft.) }\end{array}$} \\
\hline & & & & Case I & Case II \\
\hline Ion Bolling & 610 & 3.95 & 2.64 & 21.4 & 28.1 \\
\hline Boiling & 630 & 4.83 & 3.79 & 31.1 & 41.2 \\
\hline Boiling & 676 & 5.56 & 4.27 & 35.6 & 48.0 \\
\hline Bolling & 712 & 5.51 & 4.43 & 27.1 & 51.0 \\
\hline Boiling & 759 & 5.38 & 4.36 & 37.0 & 51.1 \\
\hline
\end{tabular}

Case I Solution level $5 \mathrm{~cm}$ below top of sphere at just non-bolling, no condensate hold up in condenser.

Case II Solution level $5 \mathrm{~cm}$ below top of sphere at $20^{\circ} \mathrm{C}$, no condensate hold up in condenser. 
24

Drying \# 20332

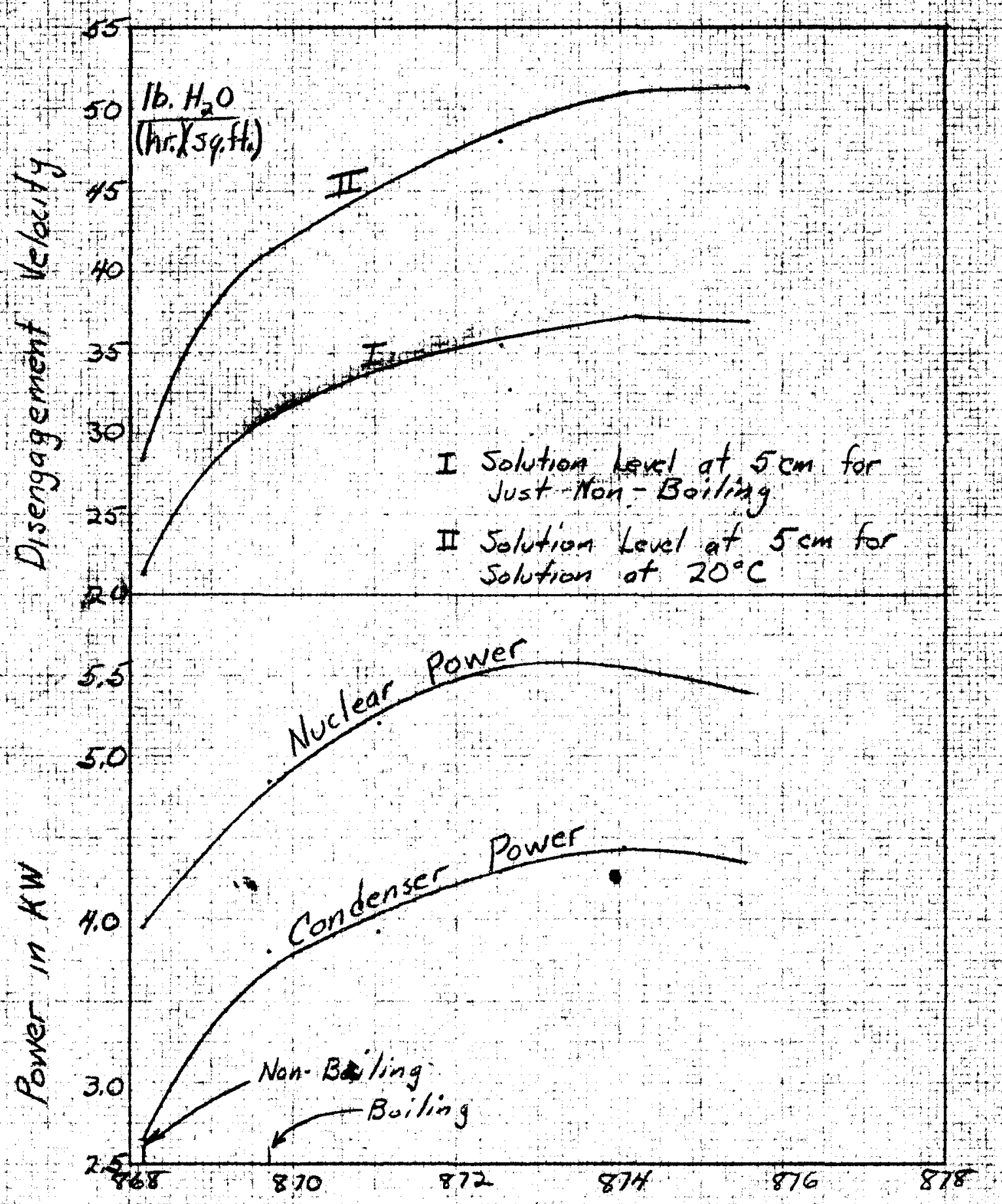

Grams $U^{235}$ in Sphere.

Figure 3. Effect of Reactivity Addition to SUPO Model of Water Boiler on the Power and Disengagement Velocity

$$
6516
$$




\section{5}

The first case gives disengagement velocities for bolling conditions of from 31.1 to $37.1 \mathrm{lbs} . /(\mathrm{hr}).(\mathrm{sq} . \mathrm{ft.})$ and there appears to be a slight decrease In the disengagement velocity for the greatest amount of reactivity added corresponding to the observed decrease in nuclear power. The second case gives disengagement velocities for bolling conditions of from 41.2 to $51.1 \mathrm{lbs} . /(\mathrm{hr}$. (sq. ft.) and no decrease in the disengagement velocity even for the greatest amount of reactivity added. This is due to the increased dependence of solution area on solution volume as the solution level is raised.

\section{DISCUSSIOR}

In the critical non-boiling calculation, the value of $k$ decreased from 1.48 to 1.40 on going from the first approximation to the third approximation. For the maximm reactivity addition the ratio of the densities $\left(a_{0} / d\right)$ increased from 1.006 to 1.008 in going from the first to the third approximation. Thus, a rather large change in the assumed $k$ had only a slight effect on the density rat1o. This indicates that, despite any uncertainties in $k$ introduced by the method of calculation, the calculated density ratio gives a good estimate of the true value.

Comparison of the $\Delta \mathrm{k}$ given by the two approximations shows agreement to within $6 \%$. Further, a comparison of the calculated $\Delta \mathrm{k}$ with velues given by direct calibration ${ }^{(5)}$ shows that the calculated $\Delta \mathrm{k}$ flgures are consistently

(5) I.D.P. King, Private Comminication to P. C. Zmola (Jan. I2, 1952) gave a figure of 3.0 grams equivalent of U235 equal to $0.1 \%$ in $\mathrm{k}$ for conditions near the bolling point for the Supo model of the Water Boller. 
about $40 \%$ too high. This indicates that the reliability of the calculated method is good since it predicts the trend of reactivity variation correctly, although the magnitude of the reproduction constant may not be given exactly.

Several reasons may be advanced for the decrease of nuclear power with reactivity addition observed in the first serles of tests. It was suggested $(6)$ that the apparent loss of reactivity was due to the removal of water from the cooling colls by steam pressure. This was checked by King in another serles of tests in which the cooling colls were maintained under a constant head of about $5 \mathrm{ft}$. of water. He Indicated that more reasonable results were obtained. Another possibility is that at the higher nuclear power the condenser became overloaded with condensate and so did not drain free. This also would cause water removal from the system, and consequent loss of moderation. Finally the results of Figure 3 indicate that there might have been saturation in the (Ibs. of steam evaporated)/(hr.)(sq. ft.). It is probable that a combination of all three effects was responsible for the observed effect.

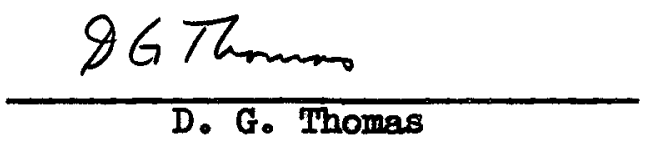

/tks

(6) L.D.P. King, Private commication, (Ioc. cit.) 
NOMENCIATURE

$D_{\text {Ic }} \quad$ Fast diffusion coefficient in the core

$D_{2 c} \quad$ Slow diffusion coefficient in the core

$D_{\text {Ir }} \quad$ Fast diffusion coefficient in the reflector

$D_{2 r}$ Slow diffusion coefficient in the reflector

d Solution density

$f$ Thermal utilization, $\Sigma_{a}(25) / \Sigma_{a}(a 11)$

k Reproduction constant $=\epsilon \mathrm{pP} \eta$

I2c Diffusion length in the core

$I_{2 x}$ Diffusion length in the reflector

N Number of atoms per cu. cm.

p Resonance escape probablitity

$S_{1} \quad$ Coupling coefficient $\left(D_{1 c} / \tau_{c} D_{2 c}\right) /\left(1 / I_{2 c}{ }^{2}\right)+\mu^{2}$

$\mathrm{S}_{2} \quad$ Coupling coefficient $\left(D_{1 c} / \tau_{c} D_{2 c}\right) /\left(1 / I_{2 c}\right)^{2}-\nu^{2}$

$S_{3} \quad$ Coupling coefficient $\left(D_{I_{r}} / \kappa_{r} D_{2 r}\right) /\left(1 / I_{2 r}\right)^{2}-\left(1 / \tau_{r}\right)$

$\mathrm{X} \quad(\sin \mu \mathrm{r}) / \mathrm{r}$

$X^{\prime} \quad$ First derivative of $X$ with respect to $r$, evaluated at core reflector interface

$Y \quad\left(\sinh \nu_{r}\right) / r$

$Y^{2} \quad$ First derivative of $Y$ with respect to $r$, evaluated at corereflector interface

$z_{I} \quad\left(e^{-r /\left(\varepsilon_{r}\right)^{I / 2}}\right) / r$

$z_{I}^{\prime} \quad$ First derivative of $z_{1}$ with respect to $r$, evaluated at corereflector interface

$z_{2} \quad\left(e^{-r / L_{2 r}}\right) / r$

$z_{2}{ }^{\prime} \quad$ First derivative of $z_{2}$ with respect to $r$, evaluated at corereflector interface 
28

19.

$B(x)$ valecules (x)/atom total uranium

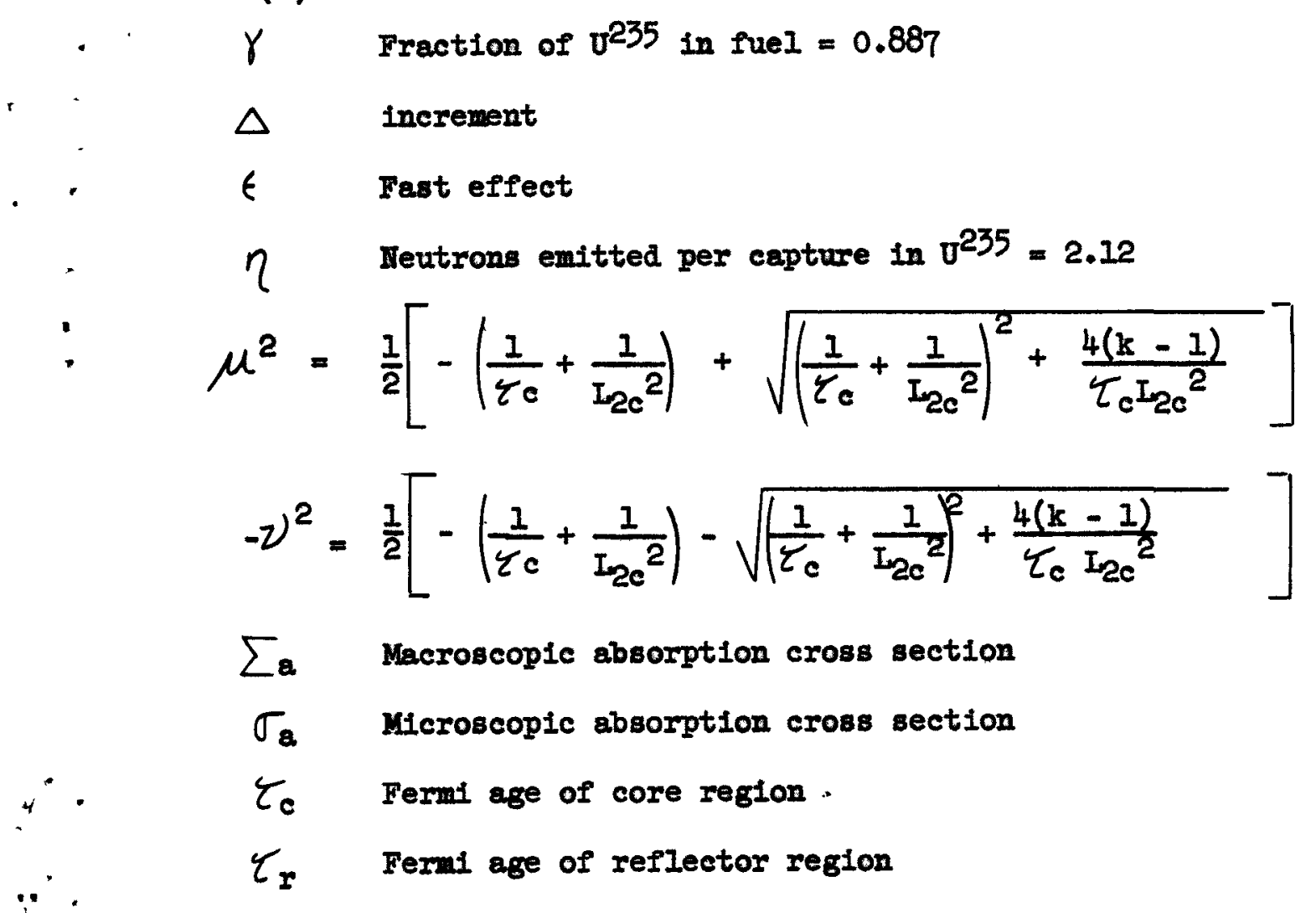

